\title{
Antidiarrheal activity of extracts from Maytenus gonoclada and inhibition of Dengue virus by lupeol
}

\author{
FERNANDO C. SILVA ${ }^{1}$, VANESSA G. RODRIGUES ${ }^{2}$, LUCIENIR P. DUARTE ${ }^{2}$, IVANA S. LULA ${ }^{2}$, RUBEN \\ D. SINISTERRA ${ }^{2}$, SIDNEY A. VIEIRA-FILHO ${ }^{3}$, RODRIGO A.L. RODRIGUES ${ }^{4}$, ERNA G. KROON ${ }^{4}$, \\ PATRÍCIA L. OLIVEIRA ${ }^{4}$, LUIZ M. FARIAS ${ }^{4}$, PAULA P. MAGALHÃES ${ }^{4}$ and GRÁCIA D.F. SILVA ${ }^{2}$ \\ ${ }^{1}$ Universidade do Estado de Minas Gerais, Departamento das Licenciaturas, \\ Avenida Paraná, 3001, 35501-170 Divinópolis, MG, Brazil \\ ${ }^{2}$ Universidade Federal de Minas Gerais, Departamento de Química, Instituto de Ciências \\ Exatas, Avenida Antônio Carlos, 6627, 31270-901 Belo Horizonte, MG, Brazil \\ ${ }^{3}$ Departamento de Farmácia, Escola de Farmácia, Universidade Federal de Ouro Preto, \\ Campus Morro do Cruzeiro, 35400-000 Ouro Preto, MG, Brazil \\ ${ }^{4}$ Departamento de Microbiologia, Instituto de Ciências Biológicas, Universidade Federal de Minas \\ Gerais, Avenida Antônio Carlos, 6627, 31270-901 Belo Horizonte, MG, Brazil
}

Manuscript received on February 2, 2016; accepted for publication on June 20, 2016

\begin{abstract}
Diarrhea is an infectious disease caused by bacterial, virus, or protozoan, and dengue is caused by virus, included among the neglected diseases in several underdeveloped and developing countries, with an urgent demand for new drugs. Considering the antidiarrheal potential of species of Maytenus genus, a phytochemical investigation followed by antibacterial activity test with extracts of branches and heartwood and bark of roots from Maytenus gonoclada were conducted. Moreover, due the frequency of isolation of lupeol from Maytenus genus the antiviral activity against Dengue virus and cytotoxicity of lupeol and its complex with $\beta$-cyclodextrins were also tested. The results indicated the bioactivity of ethyl acetate extract from branches and ethanol extract from heartwood of roots of $M$. gonoclada against diarrheagenic bacteria. The lupeol showed potent activity against Dengue virus and low cytotoxicity in LLC-MK 2 cells, but its complex with $\beta$-cyclodextrin was inactive. Considering the importance of novel and selective antiviral drug candidates the results seem to be promising.
\end{abstract}

Key words: Antidiarrheal, Celastraceae, Pentacyclic Triterpene, Antiviral Activity.

\section{INTRODUCTION}

Diarrheal disease is a worldwide health problem associated with high morbidity and mortality rates mainly in underdeveloped countries. Most cases of infectious acute diarrhea are self-limited meaning

Correspondence to: Fernando César Silva

E-mail: fcsquimico@yahoo.com.br that they resolve on their own. However, there are recommendations relative to antimicrobial treatment for some specific situations. Despite of the low percentage of cases that fulfill this requirement the huge prevalence of the disease makes antimicrobial therapy addressing the etiological agents of the process a relevant matter. Additionally raising drug resistance rates has been 
observed among diarrheagenic bacteria (Kaper et al. 2004, Navaneethan and Gianella 2008). Hence the search for more safe and effective antimicrobial compounds should be stimulated.

Plant-based medicines have been used for thousands of years in traditional systems of health care to treat a wide range of ailments caused by microorganisms. The search for plants with broad pharmacological activities, but of low toxicity has increasingly gained importance in recent years (Ahmed et al. 2013). Species of the Maytenus genus have been used in traditional medicine in Brazil and other countries to treat patients with diarrhea (Ahmed et al. 2013, Santos et al. 2007, Baggio et al. 2009). It was demonstrated that some of these species exhibited antimicrobial activity (Rodrigues et al. 2012). Maytenus gonoclada Mart. (Celastraceae) is native of "cerrado" regions and rupestrian fields of Southeastern and Northeastern Brazil. It is popularly named "Tiuzinho" and its extracts are rich in triterpenes, such as lupeol (Silva et al. 2011a). This class of compounds displays different biological activities (Rodrigues et al. 2015). Lupeol exhibits antiviral activity, in particular with respect to herpes simplex virus type 1 (HSV-1) and Epstein-Barr virus (EBV) (Tanaka et al. 2004). Data obtained from in vitro and in vivo studies are promising and further evaluation of lupeol as a candidate to therapeutic agent for human diseases seems justifiable (Siddique and Saleem 2011).

In regard to drug formulation the inclusion of active compounds into cyclodextrins has proved to be a very promising alternative due to the possibility of controlled drug release, which present many potential applications (Ioele et al. 2014). The cyclodextrins are macrocyclic oligosaccharides built from glucose units connected by $\alpha-(1,4)$ glycosidic bonds that may interact with a variety of compounds. Studies involving inclusion of active compounds into cyclodextrins show several advantages, such as dissolution rate, bioavailability, and decreasing toxicity (Loftsson and Brewster 1996, Szejtli 1998). The most common cyclodextrin is the $\beta$-cyclodextrin $(\beta C D)$, which is constituted of seven glucopyranose units. The structure of cyclodextrin provides the formation of an internal lipophilic cavity, and the external surface is hydrophilic. The lipophilic cavity of cyclodextrin provides a microenvironment into which appropriately sized non-polar moieties can enter to form inclusion complexes (Loftsson and Brewster 1996).

The present study aimed at searching for antidiarrheagenic activity of extracts and compounds obtained from $M$. gonoclada. In addition, it was evaluated the lupeol and its $\beta$-cyclodextrin complex against LLC-MK 2 cells and Dengue virus 2 (DENV-2).

The extracts from branches and from heartwoods and barks of roots of M. gonoclada furnishing the compounds 3,7-dioxofriedelane (1) (Mahato and Kundu 1994), 3-oxo-11 $\alpha$-hydroxylup20(29)-ene (2) (Alves et al. 2000), 33,29-dihydroxyglutin-5-ene (3) (González et al. 1987), tingenone (4) (Sotanaphun et al. 1998), lupeol (5) (Burns et al. 2000), and 3-O- $\beta$-D-glucosil- $\beta$ sitosterol (6) (Lendl et al. 2005) (Figure 1).

\section{MATERIALS AND METHODS}

\section{PLANT MATERIAL}

The roots and branches of $M$. gonoclada were collected in Serra da Piedade, Caeté municipality, Southeastern Brazil, avoiding damages to the specimen. The identification was confirmed by Dr. Rita Maria Carvalho-Okano, Universidade Federal de Viçosa, Viçosa municipality, Southeastern Brazil. Voucher specimens were deposited in the Herbarium of the Universidade Federal de Minas Gerais, Belo Horizonte municipality, Southeastern Brazil, under the code HBCB 60280. Each plant material was dried over kraft paper, at room temperature and then fragmented by a knife mill. 


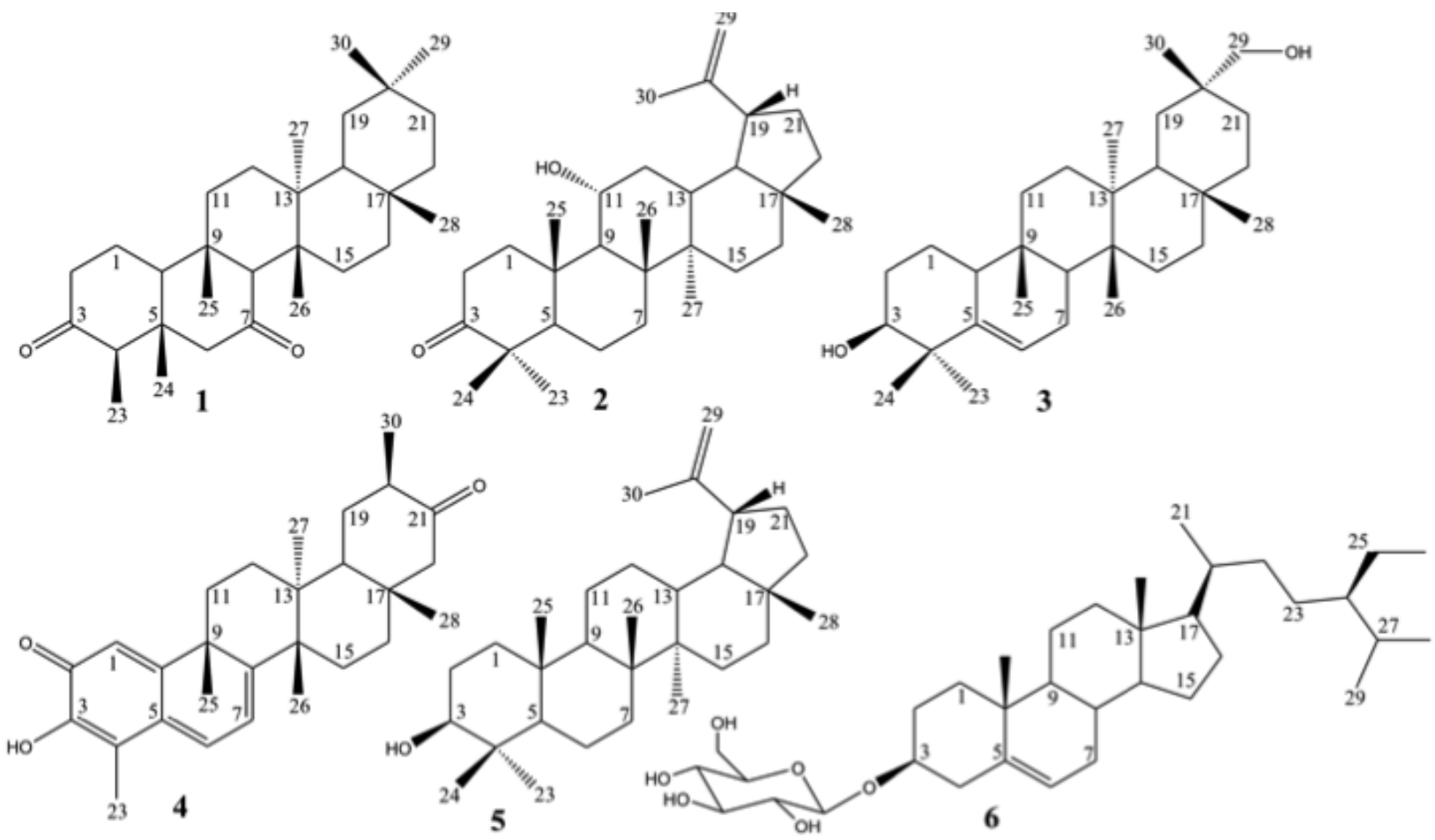

Figure 1 - Chemical structures of compounds isolated from extracts from Maytenus gonoclada.

\section{GENERAL PROCEDURES}

Column chromatographic (CC) processes were executed using silica gel 60 (0.063-0.200 mm) as stationary phase, and organic solvents pure or in mixtures of crescent polarity were used as mobile phase. Silica gel 60 (Merck) was used to prepare plates $(0.25 \mathrm{~mm})$ for analytic thin layer chromatography (TLC). The ${ }^{1} \mathrm{H}$ and ${ }^{13} \mathrm{C}$ NMR spectra were obtained on Bruker Avance DPX-200 or DRX-400, operating at $300 \mathrm{~K}$. The chemical shifts $(\delta)$ were expressed in parts-permillion (ppm) and coupling constants $(J)$ were registered in Hertz (Hz). Tetramethylsilane (TMS) was used as internal standard $\left(\delta_{\mathrm{H}}=\delta_{\mathrm{C}}=0\right)$. The infrared spectra (IR) (ATR, 400-4000 $\mathrm{cm}^{-1}$ ) were obtained on Spectrum One Perkin Elmer. Melting points were determined on MQAPF-302 apparatus (Microquímica Equipamentos Ltda) to ensure the purity of the compounds.

\section{EXTRACTION AND ISOLATION OF COMPOUNDS}

The extracts from branches and from heartwoods and barks of roots of $M$. gonoclada were extracted using different solvent systems, according to a methodology adapted from Torres-Romero et al. (2010). The powder of branches $(1.0 \mathrm{~kg})$ was sequentially submitted to extraction in a Soxhlet apparatus, producing the hexane (GAH), chloroform (GAC), ethyl acetate (GAF1) and ethanol (GEF1) extracts. The isolation of constituents from branches was performed in accordance to methodology previously reported (Silva et al. 2011a, b, 2013). Roots were separated into barks $(250.0 \mathrm{mg})$ and heartwoods $(750.0 \mathrm{mg})$ and then also subjected to extraction in a Soxhlet apparatus, with hexane/ ethyl ether (1:1) (CHF1 and RHF1), chloroform (CC and RC), ethyl acetate (CAF1 and RAF1), and finally with ethanol (CEF1 and REF1) (C indicates heartwood and $\mathrm{R}$ indicates bark of roots). 
All solutions were concentrated under vacuum in a rotatory evaporator. $\mathrm{CHF} 1, \mathrm{RHF} 1, \mathrm{CC}$, and $\mathrm{RC}$ were submitted to column chromatography using Sephadex LH-20 as stationary phase eluted with a mixture of hexane/chloroform/methanol (2:1:1). The fractions were subjected to successive silica gel chromatography yielding the constituents. The hexane/ethyl ether extract from bark roots (RHF1) furnished the compounds (1) $(13.6 \mathrm{mg}$; eluted with hexane/ethyl acetate 92:08), (2) (24.3 mg; eluted with hexane/ethyl acetate 88:12), (3) (15.1 mg; eluted with hexane/acetone 86:14) and (4) (12.2 $\mathrm{mg}$; hexane/acetone 85:15). The chloroform extract from roots bark (RC) furnished the compound (4) $(9.0 \mathrm{mg}$; eluted with hexane/ethyl acetate 80:20). The chloroform extract from heartwoods (CC) furnished the compounds (5) $(36.0 \mathrm{mg}$; eluted with ethyl acetate 94:06) and (6) (10.0 mg; eluted with ethyl acetate 90:10). Pure compounds were not isolated from the hexane/ethyl ether from heartwoods (CHF1). Spectral analysis (IR, ${ }^{1} \mathrm{HNMR},{ }^{13} \mathrm{C} \mathrm{NMR}$ ) and comparison with literature data allowed the identification of the compounds recovered.

\section{CYCLODEXTRIN COMPLEX PREPARATION AND IDENTIFICATION}

The cyclodextrin complex of (5) was performed with $\beta$-cyclodextrin ( $\beta C D)$ (Cerestar, USA). The $\beta C D$ and (5) were dissolved in hydro-alcoholic solution $(2: 1 \mathrm{v} / \mathrm{v})$ at $\mathrm{pH}=10.0 \pm 0.5$. Resulting solutions were stirred for 24-48 h. After complete dissolution, solutions were dried in a Mini Spray Dryer (B-290, Buchi, Switzerland) coupled to the Inert Loop B-295. The general conditions of operation of the Spray Dryer were the use of nitrogen gas $\left(\mathrm{N}_{2(\mathrm{~g})}\right)$ to maintain an inert atmosphere, inlet temperature of $100{ }^{\circ} \mathrm{C}$, flow spray $30 \mathrm{NL} \cdot \mathrm{h}^{-1}$ $\left(400 \mathrm{~L} \cdot \mathrm{h}^{-1}\right)$, aspirator $100 \%\left(38 \mathrm{~m}^{3} \cdot \mathrm{h}^{-1}\right)$, pumping of the sample flow $30 \%\left(8.4 \mathrm{~mL} \cdot \mathrm{min}^{-1}\right)$ and outlet temperature in the range of $35-40{ }^{\circ} \mathrm{C}$. The solid obtained was collected by a cyclone in a collection bottle and kept under vacuum in a desiccator. Thermogravimetric analysis (TG) and differential thermal analysis (DTA) were carried out in a Shimadzu thermobalance Netzsch DTA/TGA STA 409 EP using nitrogen gas purge atmosphere at $100 \mathrm{~mL} \mathrm{~min}{ }^{-1}$ and heating rate of $10^{\circ} \mathrm{min}^{-1}$. The complex (about $5 \mathrm{mg}$ ) was analyzed in a range from 25 to $700{ }^{\circ} \mathrm{C}$ in open aluminum pan $\left(\mathrm{Al}_{2} \mathrm{O}_{3}\right)$ and empty aluminum pan was used as reference. DTA curves of free molecule, lupeol/ $\beta C D$ were obtained simultaneously with the TG experiments. NMR spectra were recorded on a Bruker DRX400AVANCE spectrometer operating at $400 \mathrm{MHz}$ an equipped with a $5 \mathrm{~mm}$ inverse probe with $\mathrm{z}$-gradient coil probe. ${ }^{1} \mathrm{H}$ ROESY contour maps were acquired using ROESY spin lock time of $550 \mathrm{~ms}$. The experiments were recorded at $27{ }^{\circ} \mathrm{C}$ and no spin diffusion was observed. The NMR samples were prepared in $\mathrm{EtOH}-d_{6} / \mathrm{D}_{2} \mathrm{O}(2: 1)$ as the solvent and water suppression was achieved using presaturation and WATERGATE suppression techniques.

BIOLOGICAL ASSAYS

Bacterial strains and Antibacterial activity testing

Enterotoxigenic Escherichia coli (ETEC) H10407, enteropathogenic E. coli (EPEC) CDC-0126, enterohemorrhagic E. coli (EHEC) CDC EDL933, E. coli ATCC 25922, Salmonella enterica Typhimurium ATCC 14028, and Shigella flexneri ATCC 12022 were used as indicators of extracts and substances biological actives. All bacterial strains have been maintained in Brucella Broth (BBL, MD, USA) plus glycerol $10 \%$ at $-80{ }^{\circ} \mathrm{C}$. The minimum inhibitory concentration (MIC) of GAF1, GEF1, CHF1, CC, CAF1, CEF1, RHF1, RC, RAF1, and REF1 was determined by employing a microdilution method. The assay was conducted according to CLSI specifications (2013) with some adjustments. Extracts were dissolved in dimethyl sulfoxide (DMSO; Sigma, USA) and diluted in 
Mueller Hinton Broth (MH; BBL). Concentrations of 512 to $0.25 \mu \mathrm{g} \cdot \mathrm{mL}^{-1}$ of each extract were tested in duplicate. Bacterial inoculum were adjusted to match the 0.5 McFarland turbidity standard, diluted 1:10, and added to each well of microtiter plates in order to obtain a concentration of $10^{5} \mathrm{CFU}$. $\mathrm{mL}^{-1}$. Two positive controls were employed, $\mathrm{MH}$ added with bacterial strains and $\mathrm{MH}$ plus DMSO and bacterial strains. As negative controls $\mathrm{MH}$ and $\mathrm{MH}$ plus each extract were used. It was also included piperacillin/tazobactam, which combines an extended-spectrum penicillin with a $\beta$-lactamase inhibitor as a positive control. The samples were incubated under aerobiosis, at $37^{\circ} \mathrm{C}$, for $24 \mathrm{~h}$. The evaluation of antibacterial activity of the substances $\mathbf{4 , 5}$, and $\mathbf{6}$ was performed using an overlay method (Booth et al. 1977). MIC could not be determined due to the insolubility of the substances in aqueous solution. An aliquot of $10 \mu \mathrm{L}$ of each substance solubilized in chloroform $\left(5 \mathrm{mg} \cdot \mathrm{mL}^{-1}\right)$ was dropped onto the surface of Tryptic Soy Agar (Difco, MD, USA). After allowing the surface of agar plates to dry semisolid Tryptic Soy Agar (0.7\% agar w/v) added with $10 \mu \mathrm{L}$ of each tested bacterium was poured onto the plate. The samples were incubated under aerobiosis, at $37^{\circ} \mathrm{C}$, for $24 \mathrm{~h}$. All assays were performed in duplicate. Chloroform was used in the same way as to solubilize the substances did not inhibited any of the bacterial strains.

Cell culture and virus, Cytotoxicity assay, and Antiviral activity assay

The LLC-MK ${ }_{2}$ cells (ATCC CCL-7) were cultured in Dulbecco's modified Eagle's medium (DMEM; Cultilab, Brazil) added with 5\% fetal bovine serum (FBS; Cultilab), $50 \mu \mathrm{g} \cdot \mathrm{mL}^{-1}$ gentamicin, $100 \mathrm{UmL}^{-1}$ penicillin, and $5 \mu \mathrm{gmL}^{-1}$ fungizone, at $37^{\circ} \mathrm{C}$, in $5 \% \mathrm{CO}_{2}$ atmosphere. Dengue virus type 2 (DENV-2) isolated from humans in Ribeirão Preto - SP was used in the antiviral assay. Dry samples of lupeol (5) and lupeol/ $\beta C D$ were diluted in DMSO to a concentration of
$10 \mathrm{mg} \cdot \mathrm{mL}^{-1}$. The 3-(4,5-dimethylthiazol-2-yl)-2,5diphenyltetrazolium-bromide (MTT) colorimetric assay was made in a 96 well microplate, using $4 \times 10^{4}$ cells per well in DMEM supplemented with $5 \%$ FBS and incubated for $24 \mathrm{~h}$ at $37{ }^{\circ} \mathrm{C}$ in a $5 \% \mathrm{CO}_{2}$ atmosphere (Mosmann 1983). The cell medium was removed and DMSO-diluted samples that were further diluted in DMEM 2\% FBS at a concentration between 200 and $1.56 \mu \mathrm{g} \cdot \mathrm{mL}^{-1}$, added upon to the cell monolayer, and the cultures were incubated under the same conditions. Untreated cells and those treated only with DMSO were used as controls. After $48 \mathrm{~h}$ the cell supernatant was removed, $28 \mu \mathrm{L}$ of a solution of MTT $\left(2 \mathrm{mg} \cdot \mathrm{mL}^{-1}\right)$ in phosphate buffered saline (PBS) was added to each well and incubated again for 90 min under the same conditions. After that, $130 \mu \mathrm{L}$ of DMSO was added to each well, the plate was placed on a shaker for $15 \mathrm{~min}$, and absorbance was read at 540 $\mathrm{nm}$ on a spectrophotometer (Betancur-Galvis et al. 1999). The $50 \%$ cytotoxic concentration $\left(\mathrm{CC}_{50}\right)$ was obtained by linear regression analysis. The assay was made in triplicate. The virus was titrated in LLC-MK ${ }_{2}$ cells by plaque formation assay and a titer of $4 \times 10^{6}$ plaque forming units (PFU) $\mathrm{mL}^{-1}$ was obtained. For the antiviral assay, cells were cultivated in 96 wells microplates as described for the cytotoxicity assay. DMSO-diluted samples were diluted in DMEM supplemented with $2 \%$ FBS starting from $\mathrm{CC}_{50}$ at eight concentrations, added to cell monolayer concomitantly with $10^{5}$ PFU of DENV-2 and incubated for $72 \mathrm{~h}$ at $37{ }^{\circ} \mathrm{C}$ in a $5 \% \mathrm{CO}_{2}$ atmosphere. Uninfected cells and infected cells treated with DMSO were used as controls. The results of MTT assay were obtained by linear regression analysis, where the Effective Concentration of $50 \%\left(\mathrm{EC}_{50}\right)$ was calculated, as described for the cytotoxicity assay (BetancurGalvis et al. 1999). The assay was done in triplicate. The selective index (SI) is defined as the $\mathrm{CC}_{50} / \mathrm{EC}_{50}$ relation. 


\section{RESULTS AND DISCUSSION}

\section{PHYTOCHEMICAL STUDY}

Herein is reported the phytochemical study of extracts from $M$. gonoclada that resulted in the isolation of secondary metabolites [Compounds $\mathbf{1}$ to 6 (Figure 1)]. The isolation of compounds from low polarity extracts obtained from heartwoods and barks of the roots was performed, obtaining pentacyclic triterpenes as principal constituents. The chemical structures of these constituents were identified based on the respective IR, ${ }^{1} \mathrm{H},{ }^{13} \mathrm{C}$ (with DEPT-135) NMR. The spectral results were in accordance with previously reported data. In the IR spectra of the constituents were observed absorption bands correspondent to functional groups characteristic of each compound and the data were in accordance with the literature (Silverstein et al. 2007).

The study of contour maps HSQC and HMBC allows us to describe for first time the chemical shift assignments of all hydrogens of triterpene 1 and to correct the wrong values of ${ }^{13} \mathrm{C}$ NMR of literature (Table I).

The ${ }^{13} \mathrm{C}$ NMR chemical shift assignment of carbon C-15 and C-29 described in the literature were carefully corrected (Mahato and Kundu 1994, Patra and Chaudhuri 1987, Agrawal and Jain 1992, Wandji et al. 2000). The signals of carbons C-12 $(\delta$ 31.9), C-17 ( $\delta$ 34.7), C-25 ( $\delta$ 19.4), and C-26 $(\delta$ 18.4) presented in the review paper written by Agrawal and Jain (1992) were also incorrects. In previous studies on low polarity extracts from $M$. gonoclada three new pentacyclic triterpenes were isolated, and the triterpenes from friedelane series were predominant (Silva et al. 2011a, b, 2013, Oliveira et al. 2007). The tingenone (4) isolated from hexane/ethyl ether and chloroform extracts from roots is the secondary metabolite isolated exclusively from roots of plants from Celastraceae, and is considered a chemotaxonomic marker to this family (Gomes et al. 2011).
Recent approaches have been used to improve pharmaceutical properties of terpenes, including the employment of drug-delivery systems (Quintans et al. 2013). Due to pharmacological potential of lupeol, its complex with ciclodextrin was prepared. The characterization of lupeol/ $\beta C D$ complex was realized by $2 \mathrm{D}$-ROESY experiments. The ROESY contour map showed the intermolecular NOE correlation between lupeol and cyclodextrin hydrogens $\left(\mathrm{CH}_{3}-26\right) \mathrm{H}(\delta \mathrm{H} 1.07) / \delta \beta \mathrm{CD} \mathrm{H} 2 ; \mathrm{H} 4$ and $\mathrm{H} 6(\delta \mathrm{H} 3.50-3.60 ; \delta \mathrm{H} 3.67 ; \delta \mathrm{H} 3.80-3.85)$ beyond lupeol H6 $(\delta \mathrm{H} 1.54)$ and $\mathrm{H} 6(\delta \mathrm{H} 3.80$ $3.85)$ of the $\beta C D$ molecule. These correlations are coherent with the formation of the lupeol/ $\beta C D$ association complex with 1:1 molar ratio (Figure 2).

\section{EVALUATION OF ANTIBACTERIAL AND ANTIVIRAL ACTIVITY}

In order to test antibacterial activity of extracts and compounds derived from M. gonoclada some diarrheagenic agents were selected. There are two main reasons for this approach. The first of them is that infectious diarrhea is still considered as a worldwide problem associated with high mortality rates especially in developing countries. Although antimicrobial therapy targeting diarrheagenic agents is recommended only in specific situations considering the high prevalence of the disease and the increasing rates of bacterial resistance to antimicrobial drugs the search for new drugs that may be used to treat patients with diarrhea is highly desirable. Also, Maytenus species have already been described as a potential antidiarrheal agent (Santos et al. 2007, Baggio et al. 2009, Saleem et al. 2010). All bacterial strains tested in the study are members of the large family named Entrobacteriaceae that includes several clinically relevant Gram negative rods. S. flexneri and S. enterica Typhimurium are both associated with the etiopathology of inflammatory diarrhea. S. flexneri shows a high prevalence in underdeveloped regions while $S$. 
TABLE I

${ }^{1} \mathrm{H}$ and ${ }^{13} \mathrm{C}$ NMR spectral data of compound 1 in comparison to literature (Torres-Romero et al. 2010).

\begin{tabular}{|c|c|c|c|c|}
\hline $\mathbf{N}^{\mathbf{o}}$ & DEPT & $\delta_{\mathrm{C}}(1)$ & $\delta_{H} \operatorname{de}(1)$ & $\delta_{\mathrm{C}}\left(\mathrm{CDCl}_{3}\right)$ \\
\hline 1 & $\mathrm{CH}_{2}$ & 21.66 & $1.72 ; \mathrm{dd} ; J=4.8 ; 5.2$ and $13 / 2.07 ; \mathrm{m}$ & 21.6 \\
\hline 2 & $\mathrm{CH}_{2}^{2}$ & 40.89 & $2.38 ; \mathrm{m} / 2.48 ; \mathrm{m}$ & 40.8 \\
\hline 3 & $\mathrm{C}^{2}$ & 210.82 & - & 210.6 \\
\hline 4 & $\mathrm{CH}$ & 57.84 & $2.50 ; \mathrm{m}$ & 57.8 \\
\hline 5 & $\mathrm{C}$ & 47.02 & - & 47.0 \\
\hline 6 & $\mathrm{CH}_{2}$ & 56.90 & $2.25 ; \mathrm{dd} ; J=12 / 2.48 ; \mathrm{m}$ & 56.9 \\
\hline 7 & $\mathrm{C}^{2}$ & 210.35 & - & 210.2 \\
\hline 8 & $\mathrm{CH}$ & 63.51 & $2.85 ; \mathrm{s}$ & 63.4 \\
\hline 9 & $\mathrm{C}$ & 42.38 & - & 42.4 \\
\hline 10 & $\mathrm{CH}$ & 59.05 & $2.15 ; \mathrm{m}$ & 59.0 \\
\hline 11 & $\mathrm{CH}_{2}$ & 35.50 & $1.38 ; \mathrm{t} ; J=4.0 ; 4.4$ and 6.1 & 35.5 \\
\hline 12 & $\mathrm{CH}_{2}^{2}$ & 29.86 & $1.26 ; \mathrm{s} / 1.38 ; \mathrm{t} ; J=4.0 ; 4.4$ and 6.1 & 29.8 \\
\hline 13 & $\mathrm{C}^{2}$ & 39.39 & - & 39.4 \\
\hline 14 & $\mathrm{C}$ & 37.48 & - & 37.5 \\
\hline 15 & $\mathrm{CH}_{2}$ & 31.81 & $1.97 ; \mathrm{m}$ & $31.6^{\mathrm{a}}$ \\
\hline 16 & $\mathrm{CH}_{2}$ & 36.31 & $1.54 ; \mathrm{m}$ & 36.3 \\
\hline 17 & $\mathrm{C}^{2}$ & 30.14 & - & 30.1 \\
\hline 18 & $\mathrm{CH}$ & 41.81 & $1.60 ; \mathrm{m}$ & 41.8 \\
\hline 19 & $\mathrm{CH}_{2}$ & 34.94 & $1.23 ; \mathrm{m}$ & 34.9 \\
\hline 20 & $\mathrm{C}^{2}$ & 28.07 & - & 28.0 \\
\hline 21 & $\mathrm{CH}_{2}$ & 32.81 & $1.26 ; \mathrm{m} / 1.49 ; \mathrm{m}$ & 32.8 \\
\hline 22 & $\mathrm{CH}_{2}^{2}$ & 38.66 & $0.92 ; \mathrm{m}$ and $1.59 ; \mathrm{m}$ & 38.6 \\
\hline 23 & $\mathrm{CH}_{3}$ & 6.84 & $0.89 ; \mathrm{d} ; J=6.4$ & 6.8 \\
\hline 24 & $\mathrm{CH}_{3}$ & 15.18 & $0.77 ; \mathrm{s}$ & 15.1 \\
\hline 25 & $\mathrm{CH}_{3}$ & 18.28 & $1.07 ; \mathrm{s}$ & 18.2 \\
\hline 26 & $\mathrm{CH}_{3}$ & 19.24 & $0.91 ; \mathrm{s}$ & 19.2 \\
\hline 27 & $\mathrm{CH}_{3}$ & 19.48 & $1.41 ; \mathrm{s}$ & 19.4 \\
\hline 28 & $\mathrm{CH}_{3}$ & 32.11 & $1.00 ; \mathrm{s}$ & 32.1 \\
\hline 29 & $\mathrm{CH}_{3}$ & 31.57 & $1.18 ; \mathrm{s}$ & $31.8^{\mathrm{b}}$ \\
\hline 30 & $\mathrm{CH}_{3}$ & 34.57 & $0.96 ; \mathrm{s}$ & 34.6 \\
\hline
\end{tabular}

enterica prevails around the world. Regarding E. coli, several diarrheagenic pathotypes may be listed. Among them ETEC, EPEC, and EHEC should be highlighted. They are all very common agents of diarrheal disease. EPEC and ETEC stand up because of their prevalence and EHEC should be mentioned because of the severity of the associated disease (Kaper et al. 2004, Navaneethan and Gianella 2008). Only two extracts obtained from $M$. gonoclada showed activity against bacterial strains employed in the assays and MIC values varied greatly. GAF1 inhibited all tested bacteria and CEF1 was active against all organisms except $S$. enterica Typhimurium. Besides its broader activity spectrum overall GAF1 was also the most effective extract since fewer amounts of it was required to inhibited indicator strains. The lower MIC value detected (32 $\left.\mu \mathrm{g} . \mathrm{L}^{-1}\right)$ was observed for EPEC. The MIC for the other microorganisms employed was $64 \mu \mathrm{g} . \mathrm{L}^{-1}$. MIC values of CEF1 were $256 \mu \mathrm{g} . \mathrm{L}^{-1}$ against $E$. coli ATCC 25922 and $512 \mu \mathrm{g} . \mathrm{L}^{-1}$ for $S$. flexneri and also the three diarrheagenic E. coli isolated. MIC values of piperacillin/tazobactam were $0.25 \mu \mathrm{g} . \mathrm{L}^{-}$ ${ }^{1}$ for EPEC and $S$. flexneri, $0.5 \mu \mathrm{g} . \mathrm{L}^{-1}$ for ETEC, and $1.0 \mu \mathrm{g} . \mathrm{L}^{-1}$ for all of the other bacteria strains. The lupeol (5) showed no activity against any of the tested bacteria. However, it has been tested against Dengue virus due to its previously reported antiviral potential against HSV-1 and EBV (Tanaka et al. 2004). Based on its low solubility, the lupeol/ 


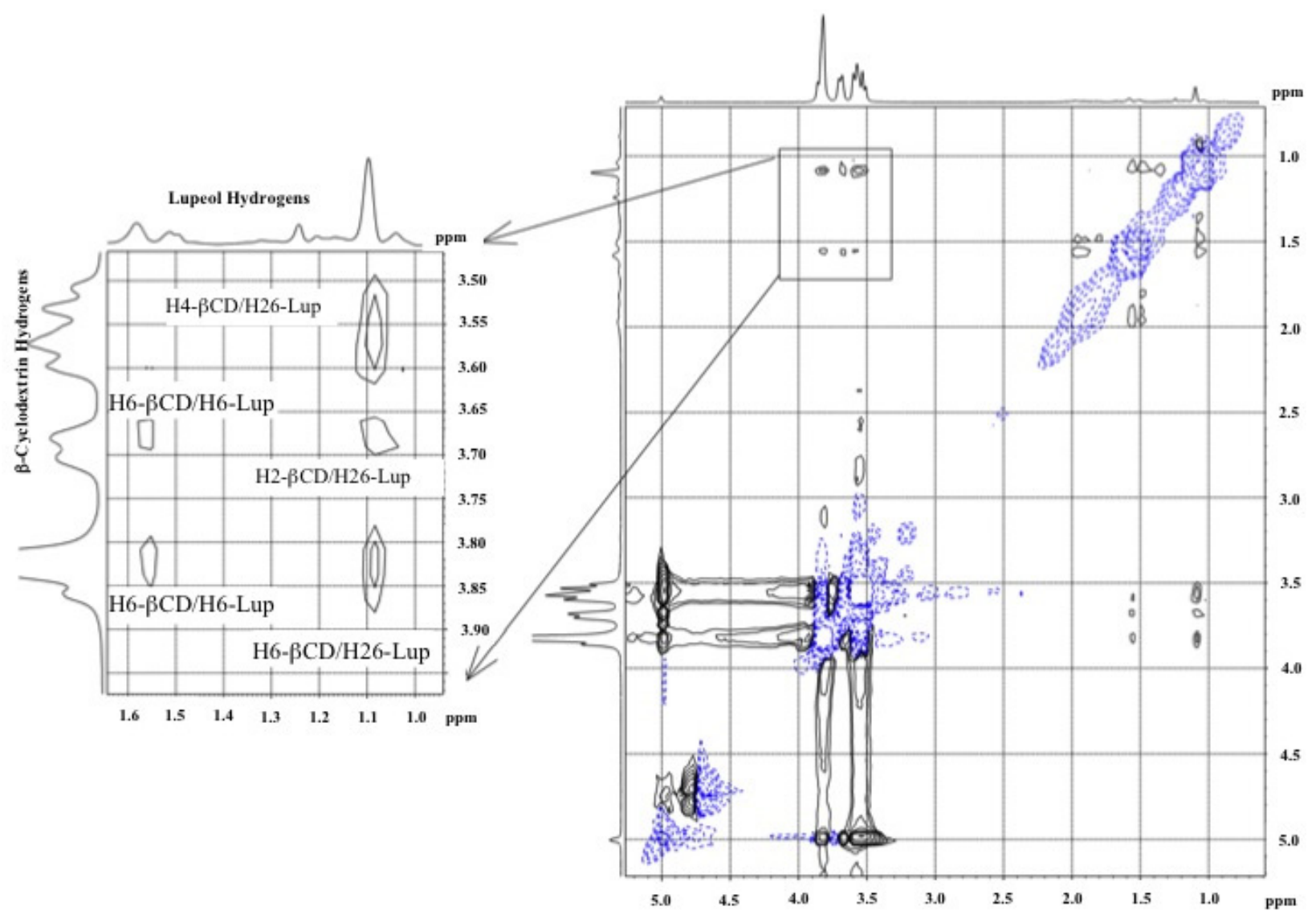

Figure 2 - ROESY contour map of lupeol/ $\beta \mathrm{CDcomplex}\left(400 \mathrm{MHz}, \mathrm{EtOH}-d_{6} / \mathrm{D}_{2} \mathrm{O}(2: 1)\right)$. For clarity, intermolecular NOE correlations are indicated.

$\beta C D$ complex was prepared and also evaluated against DENV-2. Values of $\mathrm{CC}_{50}(50 \%$ cytotoxic concentration), $\mathrm{EC}_{50}(50 \%$ effective concentration) and SI (Selective Index) of lupeol, and lupeol//BCD are depicted in Table II.

Only lupeol (5) demonstrated a potential anti-DENV-2 activity, with a $\mathrm{SI}=13.07$. The lupeol $/ \beta C D$ was not active against the virus and SI could not be calculated. As expected, inclusion complex of lupeol was less toxic compared with the molecule alone. However, this complex was not active against DENV-2. Besides, the amount of lupeol required to inhibit viral activity was 13fold less than the amount considered toxic for the cells, which indicates that lupeol cytotoxicity is not a concern for therapeutic usage. Although lupeol
TABLE II

In vitro cytotoxic and antiviral activity of lupeol (5), and inclusion complex lupeol/Bcd.

\begin{tabular}{cccc}
\hline Samples & $\mathbf{C C}_{\mathbf{5 0}}\left(\boldsymbol{\mu g} \cdot \mathbf{m L}^{-\mathbf{1}}\right)$ & $\mathbf{E C}_{\mathbf{5 0}}\left(\boldsymbol{\mu g} \cdot \mathbf{m L}^{-\mathbf{1}}\right)$ & $\mathbf{S I}$ \\
\hline Lupeol & $127.7 \pm 21.43$ & $9.77 \pm 0.90$ & 13.07 \\
Lupeol$/ \beta C D$ & $260.22 \pm 21.17$ & Not Active & - \\
\hline
\end{tabular}

exhibited a high SI, indicating that this molecule has antiviral potential against DENV-2, its exact mechanism of action is not known yet and further experiments will be conducted by our group to elucidate it. Furthermore, lupeol will be assayed against other serotypes Dengue viruses in order to prove its anti-Dengue virus activity.

The phytochemical study of M. gonoclada supports a correlation among metabolites, as 
triterpenes, and Celastraceae family showing which of these compounds are chemotaxonomic markers of this family. The present and previously phytochemical investigation showed that $M$. gonoclada is a rich source of pentacyclic triterpenes. The ethyl acetate extract from branches and the ethanol extract obtained from heartwood of the roots showed substantial antimicrobial activity against bacterial diarrheagenic agents. These results provide a scientific base for the use of species of Maytenus genus as antidiarrheal agents. The search for molecules with antiviral activity in order to find therapeutical antiviral drugs is of great importance. Considering dengue viruses, no drugs or vaccines are available, and the lupeol demonstrated to be a good candidate for this purpose since it was active against DENV-2. Further experiments will be done in order to elucidate the antiviral mechanism of this molecule as well as to search for antiviral activity against other DENV serotypes. This is the first report on the activity of lupeol against dengue viruses.

\section{ACKNOWLEDGMENTS}

The authors are thankful to the financial support provided by Fundação de Amparo à Pesquisa do Estado de Minas Gerais (FAPEMIG), Conselho Nacional de Desenvolvimento Científico e Tecnológico (CNPq), and Coordenação de Aperfeiçoamento de Pessoal de Nível Superior (CAPES).

\section{REFERENCES}

GRAWAL P AND JAIN D. 1992. ${ }^{13} \mathrm{C}$ NMR Spectroscopy of oleanane triterpenoids. Prog NMR Sp 24: 1-90.

AHMED AS, MCGAW LJ AND ELOFF JN. 2013. Evaluation of pharmacological activities, cytotoxicity and phenolic composition of four Maytenus species used in southern African traditional medicine to treat intestinal infections and diarrhoeal diseases. BMC Complement Altern Med 13: 1-15.

ALVES JS, CASTRO JCM, FREIRE MO, CUNHA EVL, BARBOSA-FILHO JM AND SILVA MS. 2000.
Complete assignment of the ${ }^{1} \mathrm{H}$ and ${ }^{13} \mathrm{C}$ NMR spectra of four triterpenes of the ursane, artane, lupane and friedelane groups. Magn Reson Chem 38: 201-206.

BAGGIO CH ET AL. 2009. Muscarinic-dependent inhibition of gastric emptying and intestinal motility by fractions of Maytenus ilicifolia Mart. ex. Reissek. J Ethnopharmacol 123: 385-391.

BETANCUR-GALVIS LA, SAEZ J, GRANADOS H, SALAZAR A AND OSSA JE. 1999. Antitumor and antiviral activity of Colombian medicinal plants extracts. Mem Inst Oswaldo Cruz 94: 531-535.

BOOTH SJ, JOHNSON JL AND WILKINS TD. 1977. Bacteriocin production by strains of Bacteroides isolated from human feces and the role of these strains in the bacterial ecology of the colon. Antimicrob Agents Chemother 11: 718-724.

BURNS D, REYNOLDS WF, BUCHANAN G, REESE PB AND ENRIQUEZ RG. 2000. Assignment of ${ }^{1} \mathrm{H}$ and ${ }^{13} \mathrm{C}$ spectra and investigation of hindered side-chain rotation in lupeol derivatives. Magn Reson Chem 38: 488-493.

CLSI. 2013. Document M100-S23. Performance Standards for Antimicrobial Susceptibility Testing; Twenty-Third Informational Supplement. Clinical and Laboratory Standards Institute, Wayne, PA.

GOMES JPM, CARDOSO CRP, VARANDA EA, MOLINA JM, FERNANDEZ MF, OLEA N, CARLOS IZ AND VILEGAS W. 2011. Antitumoral, mutagenic and (anti) estrogenic activities of tingenone and pristimerin. Braz $\mathrm{J}$ Pharmacogn 21: 963-971.

GONZÁLEZ AG, FERRO EA AND RAVELO AG. 1987. Triterpenes from Maytenus horrida. Phytochemistry 26: 2785-2788.

IOELE G, DE LUCA M AND RAGNO G. 2014. Photostability of barnidipine in combined cyclodextrin-inliposome matrices. Fut Med Chem 6: 35-43.

KAPER JB, NATARO JP AND MOBLEY HLT. 2004. Pathogenic Escherichia coli. Nature Rev Microbiol 2: 123-140.

LENDL A, WERNER I, GLASL S, KLETTER C, MUCAJI P, PRESSER A, REZNICEK G, JURENITSCH J AND TAYLOR DW. 2005. Phenolic and terpenoid compounds from Chione venosa (SW.) Urban var. venosa (Bois Bandé). Phytochemistry 66: 2381-2387.

LOFTSSON T AND BREWSTER ME. 1996. Pharmaceutical applications of cyclodextrins: Drug solubilization and stabilization. J Pharm Sci 85: 1017-1025.

MAHATO SB AND KUNDU AP. $1994 .{ }^{13} \mathrm{C}$ NMR spectra of pentacyclic triterpenoids - a compilation and some salient features. Phytochemistry 37: 1517-1575.

MOSMANN T. 1983. Rapid colorimetric assay for cellular grow and survival: application to proliferation and cytotoxicity assays. J Immunol Meth 65: 55-63. 
NAVANEETHAN U AND GIANELLA RA. 2008. Mechanisms of infectious diarrhea. Nat Clin Pract Gastroenterol Hepatol 5: 637-647.

OLIVEIRA MLG, DUARTE LP, SILVA GDF, VIEIRAFILHO SA, KNUPP VF AND ALVES FGP. 2007. 3-Oxo-12a-hydroxyfriedelane from Maytenus gonoclada: structure elucidation by ${ }^{1} \mathrm{H}$ and ${ }^{13} \mathrm{C}$ chemical shift assignments and 2D-NMR spectroscopy. Magn Reson Chem 45: 895-898.

PATRA A AND CHAUDHURI SK. 1987. Assignment of Carbon-13 Nuclear Magnetic Resonance Spectra of Some Friedelanes. Magn Reson Chem 25: 95-100.

QUINTANS JSS, MENEZES PP, SANTOS MRV, BONJARDIM LR, ALMEIDA JGRS, GELAIN DP, ARAÚJO AAS AND QUINTANS-JÚNIOR LJ. 2013. Improvement of p-cymene antinociceptive and antiinflammatory effects by inclusion in $\beta$-cyclodextrin. Phytomed 20: 436-440.

RODRIGUES VG, DUARTE LP, SILVA GDF, SILVA FC, GÓES JV, TAKAHASHI JA, PIMENTA LPS AND VIEIRA-FILHO SA. 2012. Evaluation of antimicrobial activity and toxic potential of extracts and triterpenes isolated from Maytenus imbricata. Quim Nova 35: 13751380.

RODRIGUES VG, DUARTE LP, SILVA RR, SILVA GDF, MERCADANTE-SIMÕES MO, TAKAHASHI JA, MATILDES BLG, FONSECA THS, GOMES MA AND VIEIRA-FILHO SA. 2015. Salacia crassifolia (Celastraceae): chemical constituents and antimicrobial activity. Quim Nova 38: 237-242.

SALEEM M, NAZIR M, ALI MS, HUSSAIN H, LEE YS, RIAZ N AND JABBAR A. 2010. Antimicrobial natural products: an update on future antibiotic drug candidates. Nat Prod Rep 27: 238-254.

SANTOS VL, COSTA VBM, AGRA MF, SILVA BA AND BATISTA LM. 2007. Pharmacological studies of ethanolic extracts of Maytenus rigida Mart. (Celastraceae) in animal models. Braz J Pharmacogn 17: 336-342.

SIDDIQUE HR AND SALEEM M. 2011. Beneficial health effects of lupeol triterpene: A review of preclinical studies. Life Sci 88: 285-293.
SILVA FC, DUARTE LP, SILVA GDF, VIEIRA-FILHO SA, LULA IS, TAKAHASHI JA AND SALLUM WST. 2011b. Chemical Constituents from Branches of Maytenus gonoclada (Celastraceae) and Evaluation of Antimicrobial Activity. J Braz Chem Soc 22: 943-949.

SILVA FC, OLIVEIRA MLG, RODRIGUES VG, CARVALHO SM, DUARTE LP, SILVA GDF, MIRANDA RRS, FIGUEIREDO RC, MORAES JC AND VIEIRA-FILHO SA. 2013. Triterpenes from Maytenus gonoclada and their attractive effects on Tenebrio molitor. Chem Nat Comp 49: 571-574.

SILVA FC, RODRIGUES VG, DUARTE LP, SILVA GDF, MIRANDA RRS AND VIEIRA-FILHO SA. 2011a. A new friedelane triterpenoid from the branches of Maytenus gonoclada (Celastraceae). J Chem Res 35: 555-557.

SILVERSTEIN RM, WEBSTER FX AND KIEMLE DJ. 2007. Identificação Espectrométrica de Compostos Orgânicos, $7^{\mathrm{a}}$ ed., LTC: Rio de Janeiro.

SOTANAPHUN U, SUTTISRI R, LIPIPUN V AND BAVOVADA R. 1998. Quinone-methide triterpenoids from Glyptopetalum sclerocarpum. Phytochemistry 49: 1749-1755.

SZEJTLI J. 1998. Introduction and general overview of cyclodextrin chemistry. Chem Rev 98: 1743-1753.

TANAKA T, IKEDA T, KAKU M, ZHU XH, OKAWA M, YOKOMIZO K, UYEDA M AND NOHARA T. 2004. A new lignan glycoside and phenylethanoid glycosides from Strobilanthes cusia Bremek. Chem Pharm Bull 52: 1242-1245.

TORRES-ROMERO D，KING-DÍAZ B，STRASSER RJ, JIMÉNEZ IA, LOTINA-HENNSEN B AND BAZZOCCHI IL. 2010. Friedelane Triterpenes from Celastrus vulcanicola as Photosynthetic Inhibitors. J Agric Food Chem 58: 10847-10854.

WANDJI J, WANSI JD, FUENDJIEP V, DAGNE E, MULHOLLAND DA, TILLEQUIN F, FOMUM ZT, SONDENGAM BL, NKEH BC AND NJAMEN D. 2000. Sesquiterpene lactone and friedelane derivative from Drypetes molunduana. Phytochemistry 54: 811-815. 